\title{
Elizabeth Blackwell: first woman of American medicine
}

\author{
Richard B. Gunderman ${ }^{1}$
}

Received: 7 February 2020 / Revised: 7 February 2020 / Accepted: 1 March 2020 /Published online: 18 March 2020

(C) Springer-Verlag GmbH Germany, part of Springer Nature 2020

For the first time, the number of women enrolled in U.S. medical schools has surpassed that of men, making this a fitting time to recall the first woman in the States to graduate from medical school [1]. Yet the story of Elizabeth Blackwell is far more than that of a feminine first.

Blackwell's life, work and thought embodied themes that contemporary pediatric radiologists would be well advised to attend to: the importance of sticking to core principles, celebrating diversity, advocating for the voiceless, and adopting a holistic view of health and disease. In so doing, she blazed a trail, refusing to bow to others' expectations and remaining true to her larger vision.

\section{Early years}

Elizabeth Blackwell (1821-1910) was born in England, the third of her parents' nine surviving children [2]. Her father was a singular man in his own right. Samuel Blackwell ran a sugar refining business and, as a dissenter from the Church of England, schooled his children at home.

When Elizabeth was 11, her father's business burned to the ground and the family moved to New York. Disappointed by his lack of success there, he then moved the family to Cincinnati. He hosted many lively thinkers in the family's home, which exposed Elizabeth and her siblings to controversial points of view. Unusual for his day, he believed that girls should be as well educated as boys.

Samuel Blackwell was also an ardent abolitionist, which did not always endear him to his American neighbors. He attempted, for example, to shift the production of sugar from sugar cane - a slave crop - to beets. Later, one of

Richard B. Gunderman

rbgunder@iu.edu

1 Department of Radiology, Riley Hospital for Children, Indiana University, 702 North Barnhill Drive, Room 1053, Indianapolis, IN 46202, USA
Elizabeth's brothers would have a price put on his head because he aided the escape of a female slave.

When Elizabeth was 17, her father died, leaving the family in rather dire financial straits. The elder Blackwell children went to work to support the family, and three of her older sisters founded a girls' school.

Before long Elizabeth also took up teaching, the only professional option other than nursing open to large numbers of women at the time. When an acquaintance developed cancer, she confided to Blackwell that she wished Blackwell would study medicine, saying that a great deal of her suffering could have been spared her had she only been cared for by a female physician. Blackwell, though repulsed by some of the intimacies of the human body, determined that she would enroll in medical school. She began sending letters to schools, inquiring about her prospects for admission. She wrote in her journal:

My mind is fully made up. I have not the slightest hesitation on the subject; the thorough study of medicine, I am quite resolved to go through with. The horrors and disgusts I have no doubt of vanquishing. I have overcome stronger distastes than any that now remain and feel fully equal to the contest. As to the opinion of people, I don't care one straw personally; though I take so much pains, as a matter of policy, to propitiate it, and shall always strive to do so; for I see continually how the highest good is eclipsed by the violent or disagreeable forms which contain it [3].

\section{Medicine}

Her efforts did not meet with success, however. Despite saving up money from teaching to fund her medical education and seeking mentorship from two physicians, when she went to Philadelphia with expectations of commencing her medical studies, school after school rejected her. The schools not only rejected her, they ridiculed the notion that a woman should become a physician. Some even recommended that, if she 
were truly serious about gaining admission to medical school, she should dress like a man, a fraud the high-minded Blackwell could never countenance.

Finally, in 1847, Blackwell secured admission to the Geneva Medical College in New York, where she completed the 32-week curriculum and secured her medical degree in 1849 , becoming the first woman to graduate from a U.S. medical school.

When professors and classmates suggested that Blackwell defer attendance at anatomy lectures dealing with particularly delicate structures, she demurred, insisting that such matters were as appropriate for her as for any man. She traveled to Paris where she hoped to begin practicing in a hospital, but when she was rebuffed, she took work as a nurse to enhance her clinical skills and experience.

It was there that she suffered a personal brush with serious illness. While treating infants with neonatal conjunctivitis, she acquired the infection herself. Her left eye became infected, and eventually she was forced to undergo enucleation. Her hopes of becoming a surgeon were dashed.

Blackwell then traveled to London, where she began studying at St. Bart's, regularly attending lectures by Sir James Paget. The great pathologist had described Paget disease and, along with Rudolf Virchow, would be remembered as one of the founders of the contemporary discipline of pathology.

Returning to New York to begin practicing medicine, she opened her own office, where she was determined not to turn away the poor because of their inability to pay. Yet paying patients were few, a problem she attributed to resistance to the idea of a woman physician.

Eventually, however, Blackwell's clinic began to grow and attracted additional staff, including a woman physician from Poland and Blackwell's own younger sister. In 1857 it became The New York Infirmary for Indigent Women and Children. Women played a prominent role throughout the institution, which also served as a nursing school.

Blackwell went back to Britain to secure additional funds for the infirmary, and when she returned, she shaped it into a medical college for women, with the nation's first 4-year curriculum and much more rigorous clinical experience than schools had generally provided up to that point.

When tensions between Blackwell and her equally determined sister came to a head, Blackwell left and returned to London in 1874. There, with one of her former students, she founded the London School of Medicine for Women. In 1877, she left the school and retired from the practice of medicine.

\section{Activism}

It was after her retirement from medical practice that Blackwell achieved her greatest successes as a reformer. She promoted
Christian morality, believing that science alone would prove insufficient in achieving medicine's humanitarian objectives. She felt that microbes were being overemphasized as a cause of disease and that other factors, such as purity of character and hygiene, play an equally vital role.

Blackwell sought to root out prostitution, strongly opposed vivisection, and served as an early proponent of eugenics, arguing that the important role heredity plays in health should be incorporated into policy. As these pursuits suggest, Blackwell was nothing if not a strong moralist. She pursued a career in medicine in part to protect against her own passions, writing:

I feel more determined than ever to become a physician, and thus place a strong barrier between me and all ordinary marriage. I must have something to engross my thoughts, some object in life which will fill this vacuum and prevent this sad wearing away of the heart [2].

She conceived of disease as a multi-factorial phenomenon in which bacteria might play a role but that moral, emotional and environmental facets should be given equal due. Her advocacy for women was a natural outgrowth of this view. She argued not that women deserve an equal place in medicine to that of men, but that women have a distinctive role to play in leading the profession and caring for patients. Good medicine must be guided by proper moral principles, and women have a special role to play in this regard, thanks to their greater devotion to the care of the suffering and what Blackwell called the "spiritual power of maternity." No one understands compassionate dedication, she believed, more than mothers.

Blackwell was by no means arguing that men should abandon or reduce their role in the medical profession. Instead she argued for an increased role for women. As she saw it, she was simply observing that, in addition to its scientific foundation, medicine also requires a moral one.

Only by ensuring that the moral guided the intellectual would the "beneficial influence of women in any new sphere of activity" manifest itself. She argued that prostitution and vivisection were activities that hardened the heart and dulled the moral sense, and thus could never be condoned. As mothers and potential mothers, women could best appreciate their evils.

As a result, Blackwell decried the inferior education available to most women, including what we now call premedical education, medical school and postgraduate medical studies. She argued that women were no less capable than men of grasping the scientific underpinnings of medical practice.

Blackwell also believed that men and women could be educated side by side, rather than in separate institutions and training programs. But she felt that such coeducation should not homogenize but rather accentuate the distinctive capacities of both male and female physicians. 
Beyond her concern with the roles of the sexes in medicine, Blackwell argued strongly for a holistic model of medicine. In a letter, she wrote:

I should want my Hospital to cure my patients spiritually as well as physically, and what innumerable aids that would necessitate! I must have the church, the school, the workshop ... to cure my patients - a whole society, in fact [4].

Blackwell believed that whole children could not be properly raised, educated and cared for except by a whole community. In other words, it takes a village, and Blackwell spent her medical career and her life attempting to build — and engage others in building - such villages.

Elizabeth Blackwell blazed a trail for women in American medicine. She refused to compromise her core principles, which sometimes occasioned difficulties. Instead of arguing that women were merely men's equals, she argued that they would make distinctive contributions. She was a tireless advocate for the voiceless. And she promoted a holistic model of health and disease. In these respects and many others, she serves as a role model and inspiration for all pediatric radiologists, both women and men.

\section{Compliance with ethical standards}

Conflicts of interest None

\section{References}

1. Boyle P (2009) More women than men are enrolled in medical school. Association of American Medical Colleges. https://www. aamc.org/news-insights/more-women-men-are-enrolled-medicalschool. Accessed 21 Feb 2020

2. Kline N (1997) Elizabeth Blackwell: first woman M.D. Red Wheel, Newburyport

3. Blackwell E (1895) Pioneer work in opening the medical professional to women: autobiographical sketches. Longman, Green, and Co., New York

4. Morantz RM (1982) Feminism, professionalism, and germs: the thought of Mary Putnam Jacobi and Elizabeth Blackwell. Am Q $34: 459-478$

Publisher's note Springer Nature remains neutral with regard to jurisdictional claims in published maps and institutional affiliations. 